\title{
Cold Shock in a Mesophilic and a Psychrophilic Pseudomonad
}

\author{
By JUDITH FARRELL AND A. H. ROSE \\ Department of Microbiology, University of Newcastle upon Tyne
}

(Accepted for publication 21 August 1967)

\begin{abstract}
SUMMARY
A mesophilic strain of Pseudomonas aeruginosa, grown at $30^{\circ}$ and suspended to a concentration of equiv. $0.02 \mathrm{mg}$. dry $\mathrm{wt} / \mathrm{ml}$. in $30 \mathrm{mM}-\mathrm{NaCl}$, showed rapid loss of viability when chilled rapidly from $30^{\circ}$ to $0^{\circ}$ or $-2^{\circ}$. The viability of a psychrophilic pseudomonad, grown at $30^{\circ}$, did not decrease to the same extent when a dilute suspension (equiv. $0.02 \mathrm{mg}$. dry $\mathrm{wt} / \mathrm{ml}$.) was rapidly chilled from $30^{\circ}$ to $0^{\circ}$ or $-2^{\circ}$. Concentrated suspensions (equiv. $3.0 \mathrm{mg}$. dry $\mathrm{wt} / \mathrm{ml}$.) of both the mesophile and the psychrophile released about the same proportion of total endogenous ultraviolet-absorbing compounds when rapidly chilled from $30^{\circ}$ to $5^{\circ}, 0^{\circ}$ or $-2^{\circ}$. Loss of viability following rapid chilling of a dilute suspension of the mesophile or the psychrophile was partly or completely prevented by $5 \mathrm{~mm}-\mathrm{Mg}^{2+}$ and by bacteria-free filtrates from chilled concentrated suspensions of either bacterium. The viability of the bacteria grown at $10^{\circ}$ did not decrease when dilute suspensions were rapidly chilled from $10^{\circ}$ to $-2^{\circ}$. Bacteria grown at $10^{\circ}$ contained a greater proportion of unsaturated fatty acids than bacteria grown at $30^{\circ}$. Fatty acid analyses showed that susceptibility of the mesophile and psychrophile to cold shock could be correlated with the contents of unsaturated fatty acids in their lipids.
\end{abstract}

\section{INTRODUCTION}

Sherman \& Albus (1923) reported that sudden chilling of a dilute suspension of Escherichia coli in buffer caused the death of many of the organisms. This phenomenon, which has been termed 'cold shock', has been demonstrated with other strains of E. coli (Hegarty \& Weeks, I940; Meynell, 1958) and with strains of Pseudomonas pyocyanea (aeruginosa) (Gorrill \& McNeil, 1960), Aerobacter aerogenes (Strange \& Dark, I962), Salmonella typhimurium (Gorrill \& McNeil, I960), and Serratia marcescens (Strange \& Ness, 1963). Gram-positive bacteria are thought to be insensitive to cold shock, although Ring (1965a,b) described a similar phenomenon in Streptomyces hydrogenans. Susceptibility to cold shock is usually found only in bacteria from exponential-phase cultures (Gorrill \& McNeil, I960; Houghtby \& Liston, 1965) and is greater with bacteria grown in chemically defined media than in complex media (Strange \& Ness, 1963). The decrease in viability of a population of pseudomonads is usually greater the more simple the diluent (Gorrill \& McNeil, I960).

Very little has been reported on the physiological basis of cold shock. Strange \& Dark (1962) showed that endogenous solutes, including u.v.-absorbing compounds, amino acids and ATP, were released from Aerobacter aerogenes when thick suspen- 
sions were subjected to cold shock, and they suggested that the major effect may be damage to the cytoplasmic membrane. Recent work in this laboratory (Farrell \& Rose, $1967 a, b)$ has shown that certain physiological properties of the cytoplasmic membrane are differently affected by near-zero temperatures in mesophilic and psychrophilic bacteria and yeasts. We have therefore investigated cold shock in a mesophilic and a psychrophilic Pseudomonas strain to discover whether the differences in the properties of the cytoplasmic membrane affect the susceptibility of the bacteria to cold shock.

\section{METHODS}

Organisms. The bacteria used in this study were a strain of Pseudomonas aeruginosa (NCTC 8506), one of the organisms used by Gorrill \& McNeil (I960), and a psychrophilic pseudomonad isolated from a Norwegian lake by Dr S. O. Stanley. The bacteria were maintained on nutrient-agar slopes. Stock cultures were stored in the lyophilized state.

Experimental cultures. The bacteria were grown in the medium described by Rose, Ilahi \& Kelemen (1965). Portions of glucose-free medium (900 or $1350 \mathrm{ml}$.) were dispensed into 2-1. round, flat-bottomed flasks which were plugged with cotton wool and sterilized by autoclaving at $15 \mathrm{lb}$. $/$ in. $^{2}$ for $15 \mathrm{~min}$. On cooling, the medium was supplemented with $100 \mathrm{ml}$. or $150 \mathrm{ml}$. of glucose solution $(20 \mathrm{mg} . / \mathrm{ml}$.) which had been sterilized by autoclaving at $\mathrm{Io} \mathrm{lb}$./in. ${ }^{2}$ for $10 \mathrm{~min}$. Inocula were prepared by suspending bacteria from a 24 -hr. slope culture in $6 \mathrm{ml}$. saline $(0.85 \%$, w/v). In the majority of experiments, the inoculum contained equiv. $0.1 \mathrm{mg}$. bacterial dry wt/ml., but for cultures that were to be incubated at $15^{\circ}$ or below, it contained equiv. $4.0 \mathrm{mg}$. dry wt/ $\mathrm{ml}$. One-litre portions of medium were inoculated with $4 \mathrm{ml}$. of the light or heavy inoculum; I.5-1. portions received $6 \mathrm{ml}$. inoculum. Cultures were incubated in individual Perspex baths through which was circulated water at the specified temperature. The cultures were stirred with a polytetrafluoroethylene-covered magnet $(4 \mathrm{~cm}$. long) that revolved at $1250 \mathrm{rev} . / \mathrm{min}$. Growth was measured turbidimetrically in the Hilger 'Spekker' absorptiometer (model $\mathrm{H}_{760}$ ) with neutral green-grey $\mathrm{H}_{508}$ filters and a water blank. Turbidity readings were related to dry weight by a calibration curve. Maximum specific growth rates $\left(\mu_{\max }\right)$ of the bacteria were calculated from measurements of the turbidity of cultures by using the formula:

$$
\mu_{\max .}=\frac{2 \cdot 303\left(\log x_{2}-\log x_{1}\right)}{t_{2}-t_{1}}
$$

in which $x_{2}$ and $x_{1}$ are the turbidity readings at times $t_{2}$ and $t_{1}$ during the period of maximum growth rate.

Experiments on cold shock. Bacteria from mid exponential-phase cultures (equiv. $0.26-0.34 \mathrm{mg}$. bacterial dry $\mathrm{wt} / \mathrm{ml}$.) were harvested by centrifuging at the growth temperature $\left(30^{\circ}\right.$ or $\left.10^{\circ}\right)$ at $1300 \mathrm{~g}$ in an International centrifuge (model PR-2; head no. 209) or an M.S.E. High Speed ' 18 ' centrifuge (rotor no. 69I79). In some experiments the temperature in the centrifuge bowl was continuously recorded with a thermistor probe (Grant Instruments Ltd., Toft, Cambridge) fitted to a Rustrak miniaturized temperature recorder (Grant Instruments Ltd., Toft, Cambridge); the maximum variation of temperature in the bowl was about $\pm 2^{\circ}$. The bacterial pellet was resuspended in $100 \mathrm{ml} .30 \mathrm{mM}-\mathrm{NaCl}$ at $30^{\circ}$ or $10^{\circ}$ and washed by centrifuging at $30^{\circ}$ or $10^{\circ}$ to the required concentration. Duplicate portions $(3 \mathrm{ml}$.) of the culture 
supernatant fluid and of the saline washings were filtered through membrane filters (Millipore Filter Corporation, Bedford, Massachusetts, U.S.A.; $25 \mathrm{~mm}$. diam.; 0.45 $\mu$ pore size). Portions ( $\mathrm{I} \cdot 0 \mathrm{ml}$.) of these filtrates were made up to $3.0 \mathrm{ml}$. with $30 \mathrm{mM}-\mathrm{NaCl}$ and the extinctions of the solutions were measured at $260 \mathrm{~m} \mu$ in a Unicam SP 500 spectrophotometer using cuvettes of I cm. light path.

In experiments on the effect of chilling on the viability of the bacteria, the washed suspensions were diluted with $30 \mathrm{~mm}-\mathrm{NaCl}$ at $30^{\circ}$ or $10^{\circ}$ to a concentration of equiv. $0.02 \mathrm{mg}$. dry $\mathrm{wt} / \mathrm{ml}$. Portions ( $\mathrm{I}-3 \mathrm{ml}$.) of these suspensions were dispensed into Samco tubes (Northam \& Norris, I95I) which had been incubated for I $-3 \mathrm{hr}$ in baths at the test temperature. Samples of suspension took less than I min. to reach the test temperature. Immediately after dispensing and at intervals thereafter, duplicate tubes were removed from the bath and the suspensions diluted 100,000-fold with $30 \mathrm{~mm}$ $\mathrm{NaCl}$ at $30^{\circ}$ or $10^{\circ}$. Samples $(0.1 \mathrm{ml}$.) of the diluted suspension were spread on plates of nutrient agar (Oxo Ltd., London); triplicate plates were used with each sample. The plates were incubated at $30^{\circ}$ for $48 \mathrm{hr}$ and the numbers of colonies on the plates were counted with an electric colony counter (Sintacell Ltd., London, E.C.4); all colonies were counted. Attempts were made to measure the viability of suspensions of bacteria using slide cultures (Postgate, Crumpton \& Hunter, I96I). However, the small size of the bacteria made it difficult to count the numbers of dead organisms on slide cultures. The method was therefore abandoned.

In order to study the release of endogenous solutes after chilling, portions ( $2 \mathrm{ml}$.) of dense washed suspensions (equiv. $3 \mathrm{mg}$. bacterial dry wt/ml.) were dispensed into precooled Samco tubes as already described. At intervals, duplicate tubes were removed from the bath, and the suspensions rapidly filtered through a Millipore membrane filter ( $25 \mathrm{~mm}$. diam.; $\mathrm{I} \cdot 5 \mu$ pore size) placed on another Millipore filter $(0.45 \mu$ pore size). Filtration usually took less than I min. Occasional samples filtered more slowly; these filtrations were stopped after I min. and the unfiltered portion of the suspension rejected. Portions ( $1 \cdot 0 \mathrm{ml}$.) of filtrate were diluted to $3.0 \mathrm{ml}$. with $30 \mathrm{~mm}-$ $\mathrm{NaCl}$, and the extinctions of these solutions measured at $260 \mathrm{~m} \mu$ in the Unicam SP 500 spectrophotometer with cuvettes of I cm. light path and a blank of $30 \mathrm{~mm}-$ $\mathrm{NaCl}$. These diluted filtrates were stored at $-20^{\circ}$ and later assayed for ninhydrinpositive compounds by a modification of the method of Smith \& Agiza (1957) as described by Hagen \& Rose (1962) with glycine as a standard.

Total u.v.-absorbing compounds in the bacteria were determined by centrifuging portions of washed suspensions containing equiv. $9 \mathrm{mg}$. dry wt and extracting the organisms with $3 \mathrm{ml}$. ice-cold $5 \%(\mathrm{w} / \mathrm{v})$ trichloroacetic acid. The suspensions were immediately centrifuged at $0^{\circ}$. Portions $(\mathrm{I} \cdot 0 \mathrm{ml}$.) of the supernatant were made up to $3.0 \mathrm{ml}$. with $5 \%(\mathrm{w} / \mathrm{v})$ trichloroacetic acid, and the extinctions of the solutions measured at $260 \mathrm{~m} \mu$ in cuvettes of $\mathrm{I} \mathrm{cm}$. light path with a blank of $5 \%(\mathrm{w} / \mathrm{v})$ trichloroacetic acid. Total ninhydrin-positive compounds in the bacteria were determined by placing suspensions $(3.0 \mathrm{ml}$.) containing equiv. $3.0 \mathrm{mg}$. dry $\mathrm{wt} / \mathrm{ml}$. in a bath of boiling water for $15 \mathrm{~min}$. After cooling, the cell debris was removed by centrifuging. The supernatant solution was supplemented with washings $(2 \times 0.5 \mathrm{ml}$.) of the debris and made up to $3.0 \mathrm{ml}$. with water. Portions ( $\mathrm{I} \cdot 0 \mathrm{ml}$.) of these extracts were made up to $3.0 \mathrm{ml}$. with water, and analysed for ninhydrin-positive compounds as already described.

Fatty acid analyses. Bacteria from mid exponential-phase cultures were harvested as already described. The organisms were washed once with $30 \mathrm{mM}-\mathrm{NaCl}$ and portions 
containing equiv. $250-400 \mathrm{mg}$. dry wt were suspended in I ml. water. The suspension was transferred to a $50 \mathrm{ml}$. round-bottomed flask and methanol $(5 \mathrm{ml}$.), chloroform ( $5 \mathrm{ml}$.) and glass beads (no. $3 ; \mathbf{I} \cdot 2-\mathbf{I} \cdot 4 \mathrm{~mm}$. diam.; Jencons Ltd., Hemel-Hempstead, Herts.; 5 g.) added to the flask. The stoppers were secured with Sellotape, and the flasks placed on a wrist-action shaker (Griffin and George Ltd., London; model 536-682) for $30 \mathrm{~min}$. (Trevelyan, 1966). The supernatant liquid from the suspension of disrupted organisms was decanted into a stoppered tube and the beads and debris washed with portions $(5 \mathrm{ml}$.) of methanol + chloroform mixture $(\mathrm{I}+\mathrm{I}$, by vol.). The supernatant solution and washings were pooled and centrifuged for $30 \mathrm{~min}$. at $0^{\circ}$ at I $300 \mathrm{~g}$. The clear supernatant solution was carefully transferred to a stoppered tube, and taken to dryness on a rotary evaporator (Buchler Instruments Ltd., Fort Lee, New Jersey, U.S.A.) at $40^{\circ}$. The residue was extracted with methanol $(2.5 \mathrm{ml}$.), and the extract transferred to a clean tube and taken to dryness. This procedure was repeated until no insoluble material remained in the tube. Methyl esters of the fatty acids in the extracted lipids were prepared by direct methanolysis by the method of Stoffel, Chu \& Ahrens (1959) as modified by Kates (1964a). The esters were separated by gas-liquid chromatography with a Pye Panchromatograph (W. G. Pye \& Co. Ltd., Cambridge) with a $23 \mathrm{I} \mathrm{cm} . \times 0.4 \mathrm{~cm}$. glass column containing polyethylene glycol succinate $(10 \%, \mathrm{w} / \mathrm{w})$ on Chromosorb-W (60-80 mesh). The column temperature was $170^{\circ}$ and the rate of nitrogen flow $50 \mathrm{ml} . / \mathrm{min}$. Methyl esters were detected with a flame-ionization detector (W. G. Pye \& Co. Ltd., Cambridge; cat. no. I2210) using a mixture of hydrogen $(30 \mathrm{ml} . / \mathrm{min}$.) and oxygen (I00 $\mathrm{ml} . / \mathrm{min}$.). The analyser unit amplification was $3 \times 10^{-8}$. The signal from the detector was recorded on a continuous-balance potentiometer recorder (Honeywell Controls Ltd., Newhouse, Motherwell, Lanarkshire) with a chart speed of 15 in./hr. The Panchromatograph was allowed to stabilize for at least $24 \mathrm{hr}$. before use. Portions (I $\mu \mathrm{l}$.) of extract were applied to the column with a microsyringe (Hamilton Co. Ltd., Whittier, California, U.S.A.). Methyl esters were identified by comparing their retention times with those of known fatty acid methyl esters. The areas of peaks corresponding to the separated esters were calculated by multiplying the height of the peak by the width at half the height. The retention times of methyl esters of oleic, palmitoleic and stearic acids were checked before each experiment.

Chemicals. All chemicals used were Analar or of the highest purity available commercially. Calcium-D-pantothenate, pyridoxin- $\mathrm{HCl}$ and thiamine- $\mathrm{HCl}$ were purchased from Koch-Light Laboratories, Colnbrook, Buckinghamshire. Other vitamins and amino acids were obtained from British Drug Houses Ltd., Poole, Dorset. Fatty acid methyl esters (99\% pure) were supplied by Sigma Chemical Co. Ltd., London.

\section{RESULTS}

Effect of chilling temperature on the viability of, and release of endogenous solutes from, the bacteria

Arrhenius plots of the maximum specific growth rates of the mesophilic and the psychrophilic pseudomonad (Fig. I) show that the minimum temperature for growth of the mesophile is around $5-6^{\circ}$ and that of the psychrophile around $-\mathrm{I}^{\circ}$. Previous workers demonstrated cold shock only at temperatures well below the minimum for growth of mesophilic bacteria. A comparison was therefore made of the effect of 
temperatures between $5^{\circ}$ and $-2 \cdot 5^{\circ}$ (the suspending fluid froze at approx. $-3 \cdot 0^{\circ}$ ) on the viability of, and release of endogenous u.v.-absorbing compounds from, the mesophilic and the psychrophilic pseudomonads. The data (Fig. 2) show that rapid chilling from $30^{\circ}$ to $5^{\circ}$ had little effect on the mortality of the mesophile, but that chilling to $0^{\circ}$ or $-2^{\circ}$ led to a rapid decrease in viability. Similar data were reported for cold shock on this bacterium by Gorrill \& McNeil (1960). The viability of the psychrophile did not diminish to the same extent as that of the mesophile, even when the chill temperature was $-2^{\circ}$ (Fig. 2).

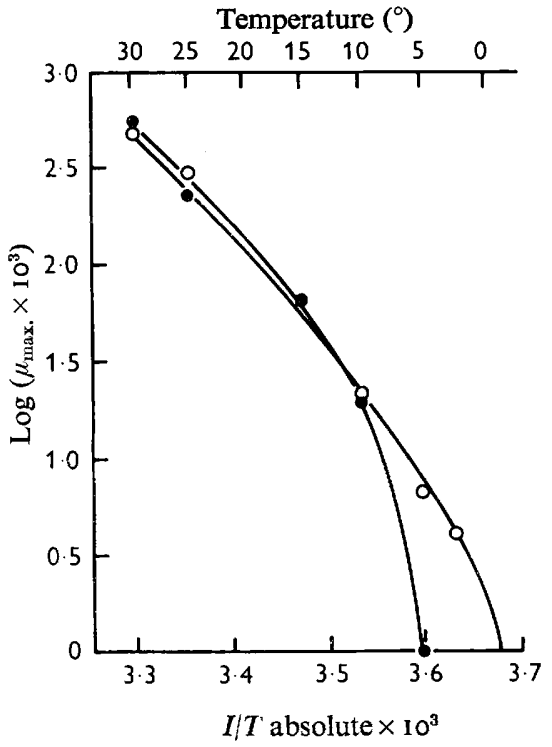

Fig. 1

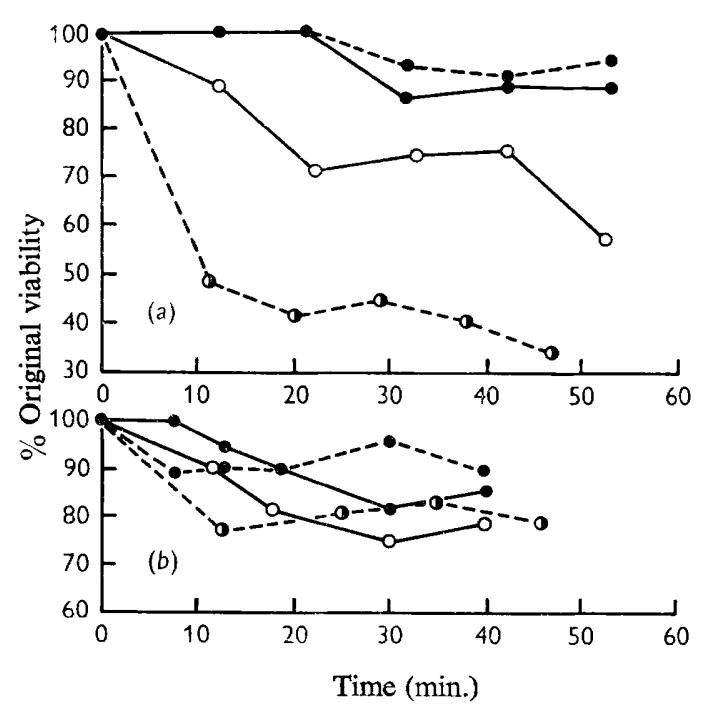

Fig. 2

Fig. I. Arrhenius plots of the maximum specific growth rates of the mesophilic Pseudomonas aeruginosa NCTC $8506(\bullet)$ and of the psychrophilic pseudomonad $(O)$.

Fig. 2. Effect of time of exposure on the viability of $(a)$ the mesophilic, and $(b)$ the psychrophilic pseudomonad grown at $30^{\circ}$ in suspensions maintained at $30^{\circ}(\bullet--\bullet)$, or chilled rapidly from $30^{\circ}$ to $5^{\circ}(-\bullet) ; 45^{\circ}$ with the psychrophile), $0^{\circ}(\mathrm{O}-\mathrm{O})$, or $-2^{\circ}(-$.$) .$ Suspensions of washed bacteria contained equiv. $0.02 \mathrm{mg}$. dry wt $/ \mathrm{ml} .30 \mathrm{mM}-\mathrm{NaCl}$.

The effects of different chilling temperatures on the release of u.v.-absorbing compounds from the mesophile and the psychrophile are shown in Fig. 3. There was a rapid release of compounds from the mesophile when a concentrated (equiv. $3.0 \mathrm{mg}$. dry wt $/ \mathrm{ml}$.) suspension was rapidly chilled from $30^{\circ}$ to $5^{\circ}$, although the total amounts released were greater from bacteria chilled to $0^{\circ}$ or $-2^{\circ}$. The amounts of u.v.-absorbing compounds released from the psychrophile at $0^{\circ}$ and $5^{\circ}$ were similar to those released from the mesophile. When the temperature was lowered to $-2^{\circ}$, filtrates from suspensions of the psychrophile had a smaller extinction at $260 \mathrm{~m} \mu$ than filtrates from suspensions chilled to $5^{\circ}$. Filtrates from cultures of both the mesophile and the psychrophile had extinctions of $0 . \mathrm{I}-0.2$ when measured at $260 \mathrm{~m} \mu$ in cuvettes of $\mathrm{I} \mathrm{cm}$. light path using a blank of uninoculated medium ( $E_{260 \mathrm{~m}_{\mu}}^{\mathbf{1 c m} .}$ (values). Moreover, despite the precautions taken to ensure that the bacteria did not experience a temperature 
stress during harvesting and washing, there was a further release of u.v.-absorbing compounds from both organisms during washing in $30 \mathrm{mM}-\mathrm{NaCl}$. The extinction readings of supernatant solutions obtained during washing of the bacteria in $30 \mathrm{~mm}-$ $\mathrm{NaCl}$ at $30^{\circ}$ were slightly greater for the mesophile than for the psychrophile. The amounts of u.v.-absorbing compounds released during washing amounted to about $50 \%$ of those that remained in the psychrophile and about $75 \%$ of the amounts retained in the mesophile.

Chilling temperature had a similar effect on the release of ninhydrin-positive compounds by the mesophile and the psychrophile. In particular, the amounts of these compounds released by the psychrophile were greater in suspensions chilled to $0^{\circ}$ than in those chilled to $-2^{\circ}$.

Table I. Effect of magnesium sulphate on the viability of the mesophilic and psychrophilic pseudomonads in suspensions rapidly chilled to $-2^{\circ}$

Bacteria were grown at $30^{\circ}$. Details of the harvesting of organisms and the preparation of suspensions are given in the text. Magnesium sulphate $(5 \mathrm{~mm})$ was incorporated in the suspending liquid $(30 \mathrm{~mm}-\mathrm{NaCl})$ and the concentration of bacteria was equiv. $0.02 \mathrm{mg}$. dry wt/ml.

\begin{tabular}{|c|c|c|c|c|}
\hline \multirow{3}{*}{$\begin{array}{l}\text { Period of } \\
\text { incubation } \\
\text { at }-2^{\circ} \\
\text { (min.) }\end{array}$} & \multicolumn{4}{|c|}{$\%$ Original viability } \\
\hline & \multicolumn{2}{|c|}{ Mesophile } & \multicolumn{2}{|c|}{ Psychrophile } \\
\hline & $30 \mathrm{~mm}-\mathrm{NaCl}$ & $\begin{array}{c}30 \mathrm{~mm}-\mathrm{NaCl}+ \\
5 \mathrm{mM}^{-\mathrm{MgSO}_{4}}\end{array}$ & $30 \mathrm{~mm}-\mathrm{NaCl}$ & $\begin{array}{c}30 \mathrm{~mm}-\mathrm{NaCl}+ \\
5 \mathrm{~mm}^{-\mathrm{MgSO}_{4}}\end{array}$ \\
\hline 0 & 100 & 100 & 100 & 100 \\
\hline 20 & 44 & 92 & 70 & 100 \\
\hline 50 & 40 & 97 & 56 & 100 \\
\hline
\end{tabular}

Table 2. Effect of chilling on the viability of the mesophilic and psychrophilic pseudomonads suspended in saline or filtrate

Bacteria were grown at $30^{\circ}$, harvested, and washed and suspended in $30 \mathrm{~mm}-\mathrm{NaCl}$ at $30^{\circ}$. Portions $\left(3 \mathrm{ml}\right.$.) containing equiv. $3.0 \mathrm{mg}$. dry $\mathrm{wt} / \mathrm{ml}$. were rapidly chilled from $30^{\circ}$ to $-2^{\circ}$ and, after $\mathrm{I} \mathrm{hr}$, were rapidly filtered through a double layer of membrane filters (see Methods for details) and the filtrates pooled. Portions of filtrate were warmed to $30^{\circ}$ and used for suspending the test bacteria at equiv. $0.02 \mathrm{mg}$. dry wt $/ \mathrm{ml}$. Portions of the dilute suspension were then either held at $30^{\circ}$ or rapidly chilled to $-2^{\circ}$. Control suspensions were made in $30 \mathrm{~mm}-\mathrm{NaCl}$.

$\%$ Viability

Temperature of suspension $\left({ }^{\circ}\right)$

\begin{tabular}{|c|c|c|c|c|c|c|c|c|c|}
\hline \multirow{3}{*}{$\begin{array}{l}\text { Bacteria suspended } \\
\text { in filtrate from }\end{array}$} & \multirow{3}{*}{$\begin{array}{l}\text { Incubation } \\
\text { period } \\
\text { (min.) }\end{array}$} & \multicolumn{4}{|c|}{-2} & \multicolumn{4}{|c|}{30} \\
\hline & & \multicolumn{2}{|c|}{ Psychrophile } & \multicolumn{2}{|c|}{ Mesophile } & \multicolumn{2}{|c|}{ Psychrophile } & \multicolumn{2}{|c|}{ Mesophile } \\
\hline & & Saline & $\widehat{\text { Filtrate }}$ & Saline & Filtrate & Saline & Filtrate & Saline & Filtrate \\
\hline \multirow[t]{2}{*}{ Psychrophile } & 0 & 100 & 100 & 100 & 100 & 100 & 100 & 100 & 100 \\
\hline & 50 & 71 & 59 & $5 I$ & 54 & 100 & 57 & 100 & 53 \\
\hline \multirow[t]{2}{*}{ Mesophile } & 0 & 100 & 100 & 100 & 100 & 100 & 100 & 100 & 100 \\
\hline & 50 & 71 & 100 & 39 & 80 & 86 & 64 & 100 & 88 \\
\hline
\end{tabular}

Protective effect of exogenous compounds

Strange \& Dark (1962) reported that sucrose (0.3 M), $\mathrm{Mg}^{2+}$ or $\mathrm{Ca}^{2+}(5 \mathrm{mM})$ and bacteria-free filtrates from chilled concentrated suspensions of exponential-phase 
Aerobacter aerogenes substantially protected a dilute suspension of their strain of A. aerogenes from the lethal effects of chilling. Incorporation of magnesium sulphate $(5 \mathrm{mM})$ in the suspending fluid gave complete, or almost complete, protection from loss of viability with both pseudomonads when dilute (equiv. $0.02 \mathrm{mg}$. dry wt $/ \mathrm{ml}$.) suspensions were rapidly chilled to $-2^{\circ}$ (Table I). Filtrates from concentrated suspensions of the mesophile that had been chilled from $30^{\circ}$ to $-2^{\circ}$, when used as the diluent, gave a considerable measure of protection against loss of viability of this bacterium when dilute suspensions (equiv. $0.02 \mathrm{mg}$. dry wt $/ \mathrm{ml}$.) were rapidly chilled from $30^{\circ}$ to $-2^{\circ}$ (Table 2). Filtrates from chilled $\left(-2^{\circ}\right)$ concentrated suspensions of the psychrophile gave some protection against loss of viability of the psychrophile

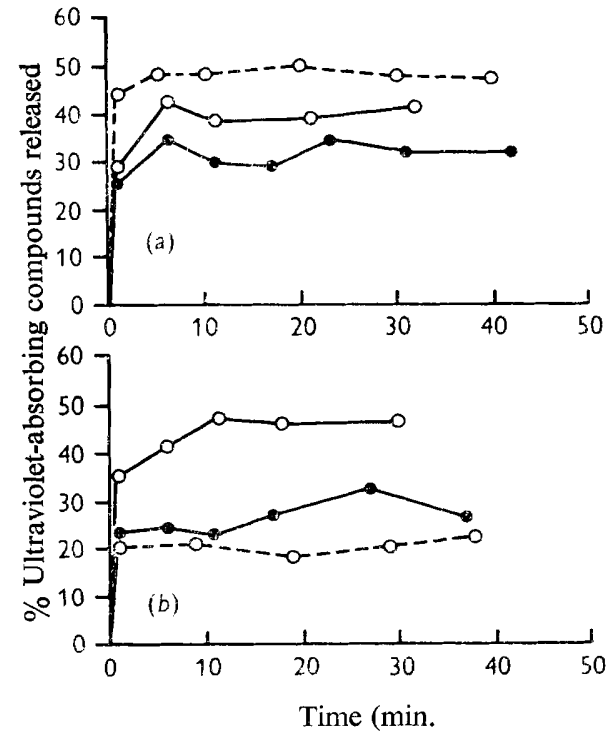

Fig. 3

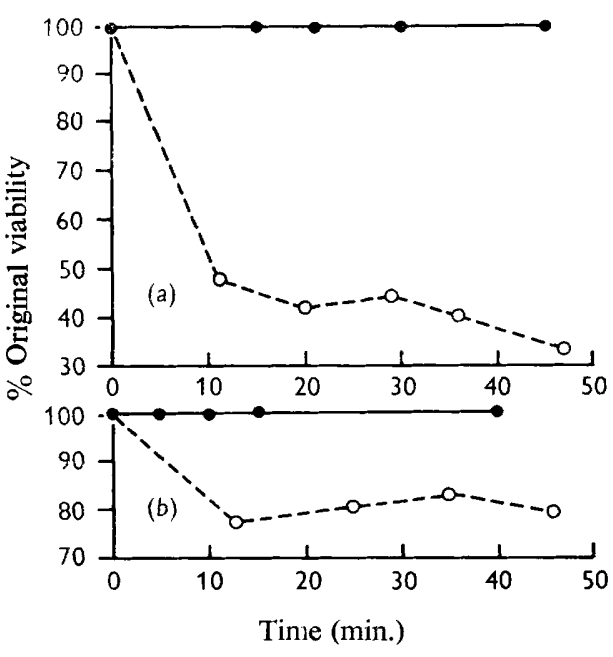

Fig. 4

Fig. 3. Effect of time of exposure on the release of ultraviolet-absorbing compounds from (a) the mesophilic, and (b) the psychrophilic pseudomonad in suspensions chilled rapidly from $30^{\circ}$ to $5^{\circ}(-0), 0^{\circ}(\mathrm{O}-\mathrm{O})$ or $-2^{\circ}(\mathrm{O}-\mathrm{O})$. Suspensions of washed bacteria contained equiv. $3.0 \mathrm{mg}$. dry wt $/ \mathrm{ml} .30 \mathrm{~mm}-\mathrm{NaCl}$.

Fig. 4. Effect of time of exposure on the viability of $(a)$ the mesophilic, and $(b)$ the psychrophilic pseudomonad in suspensions chilled rapidly from the temperature at which the organisms had been grown to $-2^{\circ}$. - indicates the response of bacteria grown at $10^{\circ}$, and $O \ldots$ that of bacteria grown at $30^{\circ}$. Suspensions of washed bacteria contained equiv. $0.02 \mathrm{mg}$. dry wt/ml. $30 \mathrm{~mm}-\mathrm{NaCl}$.

when dilute suspensions were rapidly chilled from $30^{\circ}$ to $-2^{\circ}$. The non-specific nature of this protective effect was shown by the ability of filtrates from chilled concentrated suspensions of the psychrophile to protect the mesophile against loss of viability, and of filtrates from suspensions of the mesophile to protect the psychrophile (Table 2). When filtrates from chilled concentrated suspensions of either organism were used as diluent, there was an appreciable decrease in the viability of both the psychrophile and the mesophile maintained at $30^{\circ}$. Thus, suspensions of the mesophile in saline, held at $30^{\circ}$, had a viability of $100 \%$, and of $51 \%$ when the suspension 
was chilled to $-2^{\circ}$. When the mesophile was suspended in filtrate from the psychrophile, and the suspension held at $30^{\circ}$, toxic compounds in the filtrate decreased the viability to $53 \%$. However, when a suspension of the mesophile in psychrophile filtrate was chilled to $-2^{\circ}$, there was no further decrease in viability of the mesophile. This toxic effect, which was greater with filtrates from suspensions of the psychrophile than of the mesophile, might explain the incomplete protection of viability by these filtrates with suspensions chilled to $-2^{\circ}$.

Table 3. Effect of growth temperature on the fatty acid composition of the mesophilic and psychrophilic pseudomonads

\begin{tabular}{|c|c|c|c|c|}
\hline \multirow[b]{3}{*}{ Fatty acid } & \multicolumn{4}{|c|}{$\begin{array}{l}\text { Fatty acid composition (\%) } \\
\text { Growth temperature }(\%)\end{array}$} \\
\hline & \multicolumn{2}{|c|}{30} & \multicolumn{2}{|c|}{ IO } \\
\hline & Mesophile & Psychrophile & Mesophile & Psychrophile \\
\hline $10: 0$ & - & 一 & - & - \\
\hline II:I & - & 一 & - & 一 \\
\hline I $2: 0$ & - & - & $0 \cdot 18$ & 0.10 \\
\hline I3:I & - & - & 0.42 & 0.49 \\
\hline I4:0 & $I \cdot O$ & 0.95 & 0.65 & 0.92 \\
\hline I5:0 & - & - & $\ldots$ & - \\
\hline $16: 0$ & $29 \cdot 6$ & $28 \cdot I$ & $20 \cdot 6$ & I $8 \cdot 6$ \\
\hline I $6:$ I & $18 \cdot 8$ & $23 \cdot I$ & $27 \cdot 6$ & $28 \cdot 3$ \\
\hline I7:I & - & - & - & - \\
\hline 18:0 & - & - & - & 一 \\
\hline I 8: I & 50.9 & $48 \cdot 0$ & $50 \cdot 7$ & $5 \mathrm{r} \cdot 5$ \\
\hline $18: 2$ & - & - & - & - \\
\hline$\Delta /$ mole value & 0.69 & $0.7 \mathrm{I}$ & 0.79 & 0.80 \\
\hline
\end{tabular}

Effect of growth temperature on the fatty acid composition of, and the susceptibility to cold shock in, the bacteria

At temperatures below the optimum for growth, many and probably all microorganisms synthesize increased amounts of unsaturated fatty acids (Kates, 1964 $b$; Farrell \& Rose, $1967 a, b$ ). The principal fatty acids in both the mesophilic and the psychrophilic pseudomonads, grown at $30^{\circ}$, were octadecenoic acids, with palmitic acid and hexadecenoic acids accounting for most of the remaining acids (Table 3 ). The fatty acids in the lipids extracted from the psychrophile contained a slightly greater proportion of double bonds (expressed as the $\Delta /$ mole value; Kates \& Baxter, 1962) compared with the fatty acids in lipids from the mesophile. Similar results were reported by James \& Martin (1956) for the fatty acid composition of another mesophilic strain of Pseudomonas aeruginosa. These workers also detected small amounts of a branched-chain saturated or unsaturated $\mathrm{C}_{19}$ fatty acid in their pseudomonad. However, neither of the pseudomonads examined in the present study contained detectable amounts of fatty acids containing more than 18 carbon atoms. When the pseudomonads were grown at $10^{\circ}$, the main changes in the fatty acid composition were among the $\mathrm{C}_{16}$ acids. In both the mesophile and the psychrophile, the proportion of 
hexadecenoic acids increased largely at the expense of palmitic acid. The proportion of octadecenoic acids increased slightly on lowering the temperature for growth of the psychrophile, but remained almost contant in the mesophile.

Neither the mesophile nor the psychrophile, when grown at $10^{\circ}$, showed a measurable decrease in viability when dilute suspensions (equiv. $0.02 \mathrm{mg}$. dry wt $/ \mathrm{ml}$.) were rapidly chilled from $10^{\circ}$ to $-2^{\circ}$ (Fig. 4). The amounts of u.v.-absorbing compounds released during washing of the bacteria grown at $10^{\circ}$ were about the same as those released from the organisms grown at $30^{\circ}$. No measurements were made of the release of u.v.-absorbing compounds from bacteria, grown at $10^{\circ}$, and chilled to $-2^{\circ}$.

\section{DISCUSSION}

Previous studies on cold shock have been confined to mesophilic Gram-negative bacteria, and have demonstrated a loss in viability when suspensions of the bacteria were rapidly chilled to temperatures below the minimum for growth. The data reported in the present paper show that cold shock also occurs in a psychrophilic bacterium and at temperatures just above the minimum for growth. Under the conditions used in the present study, the decrease in viability in suspensions of the psychrophile chilled to $-2^{\circ}$ was much less than in suspensions of the mesophile chilled to the same temperature. Nevertheless, cold shock in the psychrophile appears to be similar in many respects to cold shock in the mesophile, particularly with regard to the kinetics of the process and the ability of $\mathrm{Mg}^{2+}$ to protect the bacteria against loss of viability. The ability of bacteria-free filtrates from concentrated chilled suspensions of the mesophile to protect the psychrophile against loss of viability, and of filtrates from suspensions of the psychrophile to protect the mesophile, supports this contention.

Probably the most significant finding reported in the present paper is that neither the psychrophile nor the mesophile, when grown at $10^{\circ}$, showed a measurable decrease in viability when dilute suspensions were rapidly chilled to $-2^{\circ}$. This indicates that growth of the bacteria at this temperature caused certain changes in composition of the organisms such that they became insensitive to cold shock. Houghtby \& Liston (I965) reported briefly that Escherichia coli $\mathrm{K}$-I 2 became more resistant to cold shock when the growth temperature was lowered from $35^{\circ}$ to $22^{\circ}$. The best documented change in composition caused by growing micro-organisms at temperatures below the optimum for growth is the increased synthesis of unsaturated fatty acids (Kates, I964 $b$; Farrell \& Rose, $1967 a, b$ ). In view of the suggestion (Meynell, 1958; Strange \& Dark, 1962) that cold shock is accompanied by, and indeed may result from, changes in the permeability properties of the bacterial cytoplasmic membrane, it seems likely that insensitivity to cold shock in bacteria grown at $10^{\circ}$ may be associated with the increased content of double bonds in the membrane lipids. It is worth noting that the lipids from the psychrophile, grown at $30^{\circ}$, contained fatty acids with a slightly greater proportion of double bonds than fatty acids in lipids from the mesophile grown at $30^{\circ}$, and that the psychrophile grown at $30^{\circ}$ was less susceptible to cold shock than the mesophile grown at $30^{\circ}$.

Phospholipids have a liquid-crystalline nature, one result of which is that the fatty acid chains in the molecules can be in the liquid state at a temperature many degrees below the melting point of the phospholipid as determined by conventional chemical means (Byrne \& Chapman, 1964). It has also been shown by Byrne \& Chapman (1964) 
that the presence of unsaturated fatty acid residues in the phospholipid decreases the melting point of the chains. In the 'protein pore' model of membrane structure, developed by Luzzati \& Husson (1962) and embellished by ourselves (Farrell \& Rose, $1967 a, b)$, it is suggested that protein molecules are retained within pores in the membrane as a result of the mobility of the fatty acid chains in the membrane lipids. Once these chains are frozen, orientation of the protein molecules in the membrane is presumably changed. We have suggested that this change in orientation may lead to inactivation of permease activity in the membrane (Farrell \& Rose, 1967a). Another likely result of the freezing of fatty acid chains is that channels are formed in the membrane which allow the exit of intracellular low molecular-weight solutes. The data reported in the present paper show that the release of u.v.-absorbing compounds is not correlated with the loss of viability, and it is possible that the loss of other intracellular solutes is more directly responsible for death of the organisms. The possibility that freezing of the fatty acid chains in membrane lipids also causes a loss of protein from the membrane cannot be ignored. Piperno \& Oxender (1966) showed that amino acid-binding protein can be released from Escherichia coli by subjecting the organisms to osmotic shock at $0^{\circ}$. When the osmotic shock was done in the presence of $\mathrm{Mg}^{2+}$, there was no loss in viability; but when $\mathrm{Mg}^{2+}$-free diluent was used, there was an appreciable decrease in viability or the shocked bacteria.

The hypothesis that susceptibility to cold shock in Gram-negative bacteria may be a function of the content of unsaturated fatty acid residues in the membrane lipids could explain why susceptibility to cold shock in some bacteria decreases when the organisms are grown in nutritionally complex media rather than in chemically defined media (Strange \& Ness, 1963). Growth in nutritionally complex media in general leads to an increased synthesis of unsaturated fatty acids by bacteria (Kates, 1964 $b$ ).

The work reported in this paper was supported by a grant from the Science Research Council (U.K.), for which we are grateful, During the course of this work, J. F. held a Food Safety Scholarship of the Nuffield Foundation, for which we express our thanks. We are also greatly indebted to Dr R. P. Longley of this Laboratory for help and advice on gas-liquid chromatography.

\section{REFERENCES}

Byrne, P. \& ChaPMAN, D. (1964). Liquid crystalline nature of phospholipids. Nature, Lond. 202, 987. Farrell, J. \& Rose, A. H. (I967a). Temperature effects on micro-organisms. In Thermobiology. Ed. by A. H. Rose. p. I42. London: Academic Press Inc.

FARrell, J. \& Rose, A. H. (I967b). Temperature effects on micro-organisms. A. rev. Microbiol. 2I, IOI.

Gorrill, R. H. \& MCNeIL, E. M. (1960). The effect of cold diluent on the viable count of Pseudomonas pyocyanea. J. gen. Microbiol. 22, 437.

HAGEN, P.-O. \& Rose, A. H. (1962). Studies on the biochemical basis of the low maximum temperature in a psychrophilic cryptococcus. J. gen. Microbiol. 27, 89.

Hegarty, C.P. \& WeEks, O. B. (1940). Sensitivity of Escherichia coli to cold shock during the logarithmic growth phase. J. Bact. 39, 475.

Houghtby, G. \& Liston, J. (1965). Lethal cold shock of Escherichia coli K-I 2. Bact. Proc. p. I9.

JAMES, A. T. \& MARTIN, A. J. P. (I956). Gas-liquid chromatography: the separation and identification of the methyl esters of saturated and unsaturated acids from formic acid to $n$-octadecanoic acid. Biochem. J. 63, I44.

KATES, M. (I964a). Simplified procedures for the hydrolysis or methanolysis of lipids. J. lipid Res. 5, I32.

Kates, M. (1964b). Bacterial lipids. Advanc. lipid Res. 2, 17.

Kates, M. \& BAXter, R. M. (I962). Lipid composition of mesophilic and psychrophilic yeasts (Candida species) as influenced by environmental temperature. Can. J. Biochem. Physiol. 40, I 213. 
Luzzati, B. P. \& Husson, F. (I962). The structure of the liquid-crystalline phases of lipid-water systems. J. Cell Biol. 12, 207.

Meynel, G. G. (1958). The effect of sudden chilling on Escherichia coli.J. gen. Microbiol. 19, 380.

Northam, B. E. \& NorRIS, F. W. (195I). Growth requirements of Schizosaccharomyces octosporus, a yeast exacting towards adenine. J. gen. Microbiol. 5, 502.

Piperno, J. R. \& OXENDER, D. L. (I966). Amino acid-binding protein released from Escherichia coli by osmotic shock. J. biol. Chem. 24I, 5732 .

Postgate, J. R., CRumpton, J. E. \& HunTER, J. R. (1961). The measurement of bacterial viabilities by slide culture. J. gen. Microbiol. 24, I 5.

RING, K. (I965a). Der Einfluss der Adaptationstemperatur auf die Kältestabilität der Zellmembran von Streptomyces hydrogenans. Biochim. biophys. Acta 94, 598.

RING, K. $(1965 b)$. The effect of low temperature on permeability in Streptomyces hydrogenans. Biochem. biophys, res. Commun. 19, 576.

Rose, A. H., Ilahi, M. \& Kelemen, M. V. (1965). Studies on the biosynthesis of biotin. Production of biotin and biotin-like compounds by a pseudomonad. Biochem. J. 96, 319 .

Sherman, J. M. \& Albus, W. R. (1923). Physiological youth in bacteria. J. Bact. 8, I27.

Simith, A. M. \& AGIZA, A. H. (1957). The determination of amino acids colorimetrically by the ninhydrin reaction. Analyst 76,623 .

Stoffel, W., Chu, F. \& Ahrens, E. H. Jun. (1959). Analysis of long-chain fatty acids by gas-liquid chromatography. Micromethod for preparation of methyl esters. Analyt. Chem. 3I, 307.

StRANGE, R. E. \& DARK, F. A. (I962). Effect of chilling on Aerobacter aerogenes in aqueous suspension. J. gen. Microbiol. 29, 719.

Strange, R. E. \& Ness, A. G. (1963). Effect of chilling on bacteria in aqueous suspension. Nature, Lond. 197, 819.

Trevelyan, W. E. (1966). Determination of some lipid constituents of baker's yeast. J. Inst. Brew. 72 , 184. 